\title{
Alicja Pihan-Kijasowa
}

Instytut Filologii Polskiej, Uniwersytet im. Adama Mickiewicza

\section{Profesor Tadeusz Skulina - historyk języka i onomasta}

Profesor Tadeusz Skulina, rocznik 1929, urodził się 25 listopada w Katowicach, ale już od wojny, od 1941 roku, znajdował się w Wielkopolsce. W czasie wojny pracował przymusowo w niemieckim gospodarstwie rolnym w Łęgu w powiecie śremskim [Rzepka, Walczak 1994: 5]. Po wojnie ukończył w Śremie gimnazjum im. Józefa Wybickiego, uzyskując w 1950 roku maturę, po czym rozpoczął studia na poznańskiej polonistyce. Wcześnie zainteresowała go problematyka językoznawcza, szczególnie historycznojęzykowa. Zapewne w dużej mierze do rozwoju takich zainteresowań przyczynił się prof. Władysław Kuraszkiewicz, to na prowadzone przez Profesora seminarium magisterskie uczęszczał bowiem student Tadeusz Skulina. Szybko zwrócił uwagę promotora swoją sumiennością oraz niewątpliwym talentem językoznawczym. I już w 1954 roku, jeszcze jako student, został pracownikiem Uniwersytetu Poznańskiego, zatrudniony jako zastępca asystenta. Równocześnie kontynuował studia i przygotowywał rozprawę magisterską. W tym czasie prof. Kuraszkiewicz pracował nad indeksem wyrazów polskich w XVI-wiecznym łacińsko-polskim leksykonie Jana Mączyńskiego. Swojemu magistrantowi, Tadeuszowi Skulinie, w ramach pracy magisterskiej zlecił opracowanie aspektu czasowników zawartych u Mączyńskiego [Walczak 2008: 19]. Magistrant z zadania wywiązał się wzorowo i w 1955 roku na podstawie przygotowanej rozprawy uzyskał stopień magistra filologii polskiej. I choć badań nad Mączyńskim nie kontynuował, na podstawie rozprawy magisterskiej opracował obszerny artykuł $O$ aspekcie czasowników w stowniku Mączyńskiego, opublikowany w „Zeszytach Naukowych Uniwersytetu Adama Mickiewicza" [Skulina 1959a]. Nie był to jednak jego debiut naukowy. Wcześniej, w 1958 i 1959 roku w „Języku Polskim” opublikował dwie prace o tematyce współczesnej, z których jedna dotyczyła 
tłumaczenia angielskiego slangu [Skulina 1958], a druga - rzeczowników augmentatywnych wstecznie derywowanych [Skulina 1959b]. Problematyka współczesna była jednak tylko epizodem w twórczości naukowej Tadeusza Skuliny. W dalszym ciągu pozostawał pod opieką naukową prof. Kuraszkiewicza, rozwijając zainteresowania historycznojęzykowe. Podjął badania nad rozwojem grup spółgłoskowych w polszczyźnie - przeszedł więc na obszar fonetyki i dialektologii historycznej. Był to też temat jego dysertacji doktorskiej, przygotowanej pod kierunkiem prof. Kuraszkiewicza, a obronionej w 1961 roku. Rozprawa, zatytułowana Rozwój grup spółgłosek zwarto-szczelinowych w języku polskim, opublikowana w Poznaniu w 1964 roku w serii „Prace Komisji Językoznawczej Poznańskiego Towarzystwa Przyjaciół Nauk”, poprzedzona została drukiem kilku artykułów z zakresu fonetyki i dialektologii historycznej. Badacz poruszał w nich problem staropolskiej oboczności Wociech || Wojciech [Skulina 1960b], oboczności typu mieśćce || miestce [Skulina 1961], geografii językowej form rozgniewać i rozniewać [Skulina 1960a]. Każdy tekst, solidnie podbudowany materiałowo, przynosił rozstrzygnięcia istotne, które na trwałe weszły do historii języka. Najważniejszym jednak osiągnięciem Tadeusza Skuliny w zakresie badań fonetyki i dialektologii historycznej, zachowującym do dziś aktualność, ciągle cytowanym w rozprawach historycznojęzykowych, jest przywołana wyżej rozprawa doktorska o rozwoju grup spółgłosek zwarto-szczelinowych [Skulina 1964]. Zajął się w niej autor takimi problemami, jak: redukcja jednorodnych grup spółgłoskowych (wraz ze wskazaniem uwarunkowań ułatwiających lub hamujących przebieg procesu), asymilacje i dysymilacje w grupach spółgłoskowych, dyspalatalizacja bądź zachowanie miękkości w analizowanych grupach i wreszcie antycypacja miękkości. Wszystkie ustalenia, oparte na bogatym materiale obejmującym wszystkie ważniejsze zabytki staropolskie i XVI-wieczne ${ }^{1}$, poprzedzone precyzyjnymi analizami, z uwzględnieniem metody statystycznej, formułowane z należytą ostrożnością, zyskały pełną aprobatę późniejszych recenzentów i badaczy. Po latach prof. Bogdan Walczak tak ocenił tę pracę:

Rozprawa w całej pełni już ujawnia takie cechy warsztatu naukowego Tadeusza Skuliny (znamionujące wpływ szkoły profesora Kuraszkiewicza), jak

1 Jak we wstępie do książki pisze Tadeusz Skulina, podstawa materiałowa pracy obejmuje „wszystkie ważniejsze zabytki staropolskie do wieku XV włącznie” [Skulina 1964: 9] oraz liczne teksty XVI-wieczne, natomiast „,[s]łabe wykorzystanie tekstów późniejszych niż szesnastowieczne uzasadnia się tym, że podstawowe procesy fonetyczne w opisywanych grupach spółgłoskowych zachodziły w ciągu XV i XVI i to raczej w pierwszej połowie tego ostatniego, zaś wyniki tych procesów utrzymują się przez następne wieki aż do dnia dzisiejszego" [Skulina 1964: 9]. 
filologiczna akrybia, dążność do ogarnięcia możliwie najbogatszego i najrozleglejszego materiału, precyzja analizy i interpretacji, ostrożność w wyciąganiu wniosków i formułowaniu uogólnień. Dzięki tym zaletom monografia doktorska Tadeusza Skuliny weszła do podstawowego kanonu prac z zakresu fonetyki historycznej języka polskiego. [Walczak 2008: 25]

Podobnie wysoką ocenę wystawił rozprawie prof. Karol Zierhoffer, podkreślając przy tym najważniejsze dla historycznej fonetyki i dialektologii ustalenia:

1) antycypację miękkości w rzeczownikach ociec, oćca, radźca, mieśćce itp. trzeba datować na pierwsze lata XV wieku, a jej narodziny wiążą się z Wielkopolską, która stanowiła główny ośrodek tego rozprzestrzeniającego się w ciągu XV wieku procesu,

2) z Wielkopolską trzeba też łączyć rozwój liczebnikowej formacji jedenaćcie, dwanaćcie > jedenaście, dwanaście, gdyż do tej zmiany doszło tam znacznie wcześniej niż w Małopolsce i na Mazowszu. [Zierhoffer 2008b: 11-12]

Wkrótce zainteresowania naukowe Tadeusza Skuliny oprócz gruntu stricte polonistycznego objęły też obszar szerszy - slawistyczny. Już w 1963 roku opublikował artykuł Słowiańskie liczebniki 11-19 [Skulina 1963], w którym przedstawił procesy redukcyjne i ich chronologię w prasłowiańskim złożeniu *iedsnı na desęte, dokonujące się w językach słowiańskich. O dużej kompetencji slawistycznej Tadeusza Skuliny już we wczesnym okresie jego zainteresowań wschodniosłowiańskich świadczą bez wątpienia szczegółowe recenzje ważnych dla językoznawstwa rusycystycznego prac: źródłowego wydawnictwa gramot smoleńskich z XIII-XIV wieku i Słownika etymologicznego języka rosyjskiego autorstwa Mikołaja Szanskiego, opublikowane w 1965 i 1966 roku w „Roczniku Slawistycznym” [Skulina 1965; 1966]. Jednak najważniejszym dziełem sytuującym się w staroruskiej antroponimii jest dwutomowa rozprawa habilitacyjna Staroruskie imiennictwo osobowe [Skulina 1973a; 1973b], recenzowana przez mistrza Tadeusza Skuliny - prof. Kuraszkiewicza [Zierhoffer 2008a: 35]. Jak przyznaje autor: „Podjęcie sformułowanego w tytule pracy tematu zaproponował mi Pan Profesor Władysław Kuraszkiewicz" [Skulina 1973a: 6]. Badacz spuścizny Tadeusza Skuliny z zakresu antroponimii wschodniosłowiańskiej, prof. Marian Wójtowicz, pisze: ,[...] antroponimia wschodniosłowiańska przez długi czas należała do słabiej rozwiniętych dyscyplin w porównaniu z osiągnięciami onomastyki innych krajów słowiańskich" [Wójtowicz 2008: 27]² i dalej:

2 Tadeusz Skulina we wstępie do rozprawy tak o tym pisze: „Na dobrą sprawę antroponimia wschodniosłowiańska zatrzymała się w rozwoju na kilka dziesiątków lat po wybitnym osią- 
Podejmując problematykę onomastyczną, T. Skulina zdawał sobie sprawę, że przed antroponimią wschodniosłowiańską stoją dwa podstawowe zadania: 1) opracowanie nowoczesnego słownika nazw osobowych dla języka staroruskiego i starszych okresów trzech języków wschodniosłowiańskich, 2) stworzenie syntezy ukazującej historyczny rozwój systemu nazywania osób u wschodnich Słowian. [Wójtowicz 2008: 28]

Dla realizacji podjętego celu badawczego Tadeusz Skulina odbył staż naukowy w Moskwie i ówczesnym Leningradzie (obecny Petersburg), podczas którego mógł spenetrować staroruskie źródła, poznać rosyjską literaturę przedmiotu, podjąć dyskusje z rosyjskimi badaczami. Cel swojej pracy badacz określił następująco: „Zamierzeniem moim jest przedstawienie rozwoju staroruskiego nazewnictwa osobowego od najdawniejszych poświadczonych źródłowo czasów do wieku XIV włącznie" [Skulina 1973a: 5]. Przedmiotem opisu uczynił

wszelkie poświadczone w ekscerpowanych źródłach nazwy osobowe odnoszące się do mężczyzn i używane do w. XIV włącznie przez ludność etnicznie wschodniosłowiańską lub zasymilowaną. Na równi więc są traktowane imiona rodzime, nieliczne obce niechrześcijańskie oraz chrzestne, jeżeli tylko spełniony jest warunek określonej wyżej etnicznej przynależności ich właściciela. [Skulina 1973a: 9]

Poza wyborem poświadczonych w źródłach imion dokonał także rekonstrukcji imion z przymiotników dzierżawczych oraz z antroponimów żeńskich [Skulina 1973a: 12]. Myśl skupił na trzech najważniejszych problemach: a) kształtowaniu się wielostopniowego systemu antroponimicznego, b) ewolucji bazy leksykalnej staroruskiej antroponimii, c) strukturze i etymologii staroruskich nazw osobowych [por.: Wójtowicz 2008: 30; Zierhoffer 2008b: 13]. Wątkiem ubocznym, ale istotnym zwłaszcza dla historyków badających początki Rusi, jest problem imion nordyckich (skandynawskich), które są w opinii badacza

gnięciu N.M. Tupikowa, którego słownik (nb. niedokończony) nie może być już dzisiaj podstawą gruntownych, syntetycznych studiów. W następnych kilkudziesięciu latach notujemy jedynie parę niewielkich prac naukowych z tego zakresu, a dopiero w okresie powojennym, zwłaszcza w ostatnim piętnastoleciu, zaczęły się ukazywać poważne monografie szczegółowych problemów i próby syntezy wybranych zagadnień antroponimicznych" [Skulina 1973a: 7]. 
świadectwem dawnych, dziś jeszcze do końca nie wyjaśnionych stosunków wschodniosłowiańsko-normańskich [...] Istotne jest, że właśnie antroponimiczne argumenty pełnią ważną rolę w dyskusji o charakterze wpływów normańskich na Rusi. [Skulina 1973a: 13]

Bazując na dostępnych źródłach, w odniesieniu do badanego okresu siłą rzeczy fragmentarycznych, autor miał pełną świadomość, że wiele poruszanych zagadnień szczegółowych wymaga w przyszłości dalszych badań - kontynuacji i weryfikacji. Była to jednak pierwsza oryginalna, tak dogłębna i szczegółowa rozprawa o staroruskim imiennictwie. Doczekała się też wielu recenzji w czasopismach polskich i zagranicznych. Maria Malec oceniła pracę następująco: ,[...] imponując zakresem poruszanych zagadnień pobudza do dalszych, szczegółowych studiów nie tylko nad antroponimią wschodniosłowiańską" [Malec 1976: 284]. Natomiast Jan Wawrzyńczyk stwierdził, że dołączony do pracy indeks nazw osobowych ,zapewne na długo pozostanie najlepszym i najpełniejszym spisem staroruskich antroponimów X-XIV w." [Wawrzyńczyk 1975: 236]. Bez wątpienia za Bogdanem Walczakiem można powtórzyć:

Książka Staroruskie imiennictwo osobowe ze względu na swą wartość materiałową i zalety metodologiczne jest dziełem pionierskim, wybitnym i fundamentalnym. Jest pierwszą w dziejach slawistyki monografią nazewnictwa osobowego epoki staroruskiej. [Walczak 1993: 3]

Ważne miejsce w dorobku Tadeusza Skuliny z zakresu onomastyki wschodniosłowiańskiej zajmują hasła językowe opracowane dla wysoko ocenianego w nauce światowej, monumentalnego Stownika starożytności stowiańskich. W tomie 6 (części 1 i 2) oraz w tomie 7 opublikował łącznie 34 artykuły hasłowe ruskich nazw miejscowych, osobowych i plemiennych, takich jak np.: Tmurokań, Toropiec, Trembowla, Trubież, Wiaczesław, Tywercy [Słss].

Zainteresowania antroponimiczne Tadeusza Skuliny nie ograniczały się wyłącznie do imiennictwa staroruskiego. Antroponimii poświęcił też studia o charakterze metodologicznym, dotyczące przezwisk, pseudonimów i kryptonimów. Ponadto podjął badania nad ustalaniem się nazwisk w dobie średniopolskiej oraz nad dziejami polskiego nazewnictwa kobiecego. Problemowi imiennictwa kobiecego poświęcił cykl interesujących i ważnych artykułów, w których problem onomastyczny ujęty został z perspektywy socjolingwistycznej i historycznokulturowej. Zgodnie z warsztatem naukowym, ukształtowanym w szkole prof. Kuraszkiewicza, wszelkie wnioski opierał na obszernym materiale ekscerpowanym z licznych źródeł. Pozwoliło to badaczowi ustalić 
hierarchię popularności imion chrzestnych w średniowieczu (kolejno wedle popularności): Katarzyna, Anna, Matgorzata, Dorota, Barbara, Elżbieta, Jadwiga, Agnieszka, Helena, Zofia [Skulina 1987], przedstawić historię i geografię żeńskich formacji patronimicznych w staropolszczyźnie [Skulina 1993] czy też etymologię niejasnych staropolskich kobiecych nazw odosobowych [Skulina 1991]. Jak wiemy i jak wynika ze wspomnianych prac, prof. Skulina nosił się z zamiarem przygotowania monografii o polskim nazewnictwie kobiecym. Od lat pracował nad tym problemem, jednak syntezy, niestety, nie zdążył przygotować. Pozostała tylko nieukończona redakcja tej książki [Rzepka, Walczak 1994: 8-9].

Profesor Skulina przez 37 lat działalności naukowej opracował i opublikował kilkadziesiąt rozpraw [Pihan-Kijasowa 1994]. Jak oceniają autorzy artykułu, który ukazał się wkrótce po śmierci Profesora, Wojciech Ryszard Rzepka i Bogdan Walczak,

[m]ożna sobie [...] wyobrazić (są przykłady) dorobek obfitszy liczebnie i obszerniejszy objętościowo, [jednak - A.P.K.] trudno by było o dorobek o większym ciężarze gatunkowym. Jest to twórczość naukowa bardzo wysokiego lotu. W miarę upływu lat w coraz większym chyba stopniu cechowało Profesora Skulinę dążenie do naukowego perfekcjonizmu. Pod tym względem był twórczym kontynuatorem swojego mistrza [...] Profesora Władysława Kuraszkiewicza. [Rzepka, Walczak 1994: 9]

Profesor Skulina zmarł 23 listopada 1992 roku po ciężkiej, wyniszczającej chorobie. Pozostawił dorobek naukowy, który jest inspiracją dla kolejnych pokoleń badaczy, pozostawił też niedokończone prace, pomysły, których zrealizować nie zdążył. Pozostawił też uczniów - magistrów filologii polskiej, których wykształcił 160. Przedwczesna śmierć spowodowała, że zdążył wypromować tylko jednego doktora w zakresie językoznawstwa - autorkę niniejszego szkicu. Drugi rozpoczęty doktorat już zrealizowany nie został.

W biogramie uczonego - pracownika uniwersytetu - mieszczą się zawsze informacje o pełnionych funkcjach, o członkostwie w towarzystwach naukowych, o odznaczeniach i orderach. Wszystkie te elementy znajdują się w biogramie Profesora [por. Rzepka, Walczak 1994: 10-11]. Ale nie przywiązywał on do nich nadmiernego znaczenia. Był człowiekiem niebywale skromnym i prawym, człowiekiem wielkich zalet serca i umysłu. Wyróżniał się niezwykłą powściągliwością w okazywaniu emocji, jednocześnie delikatnością i taktem. Jako uczennica Profesora doświadczałam tych przymiotów nieraz. 


\section{Bibliografia}

Malec Maria (1976), [rec.:] T. Skulina, Staroruskie imiennictwo osobowe, cz. I, Wroclaw 1973, cz. II, Wroctaw 1974, „Onomastica”, t. 21, s. 274-284.

Pihan-Kijasowa Alicja (1994), Bibliografia prac Profesora Tadeusza Skuliny za lata 1958-1993, „Studia Polonistyczne”, t. 20, s. 13-17.

Rzepka Wojciech Ryszard, Walczak Bogdan (1994), Życie i działalność Profesora Tadeusza Skuliny, „Studia Polonistyczne”, t. 20, s. 5-11.

Skulina Tadeusz (1958), Na marginesie angielskiego slangu, „Język Polski”, s. 307-311.

Skulina Tadeusz (1959a), O aspekcie czasowników w słowniku Mączyńskiego, „Zeszyty Naukowe UAM. Filologia Polska 3", Poznań, s. 109-153.

Skulina Tadeusz (1959b), Rzeczowniki augmentatywne wstecznie derywowane, „Język Polski", s. 190-202.

Skulina Tadeusz (1960a), Geografia językowa form rozgniewać $i$ rozniewać $w$ staropolszczyźnie, „Język Polski”, s. 127-135.

Skulina Tadeusz (1960b), Staropolska oboczność Wojciech // Wociech, „Poradnik Językowy", z. 3, s. 113-123.

Skulina Tadeusz (1961), O staropolskiej oboczności mieśćce // miestce, „Język Polski”, s. 30-36.

Skulina Tadeusz (1963), Stowiańskie liczebniki 11-19, „Z polskich studiów slawistycznych. Seria II: Językoznawstwo”, Warszawa, s. 141-151.

Skulina Tadeusz (1964), Rozwój grup spółgłosek zwarto-szczelinowych w języku polskim, Poznańskie Towarzystwo Przyjaciół Nauk, Poznań.

Skulina Tadeusz (1965), [rec.:] Smolenskie gramoty XIII-XIV vekov, opr. T.A. Sumnikov i V.V. Łopatin, red. R.I. Avanasov, Moskva 1963, ss. 138, „Rocznik Slawistyczny”, t. 24 , s. $179-184$.

Skulina Tadeusz (1966), [rec.:] Etimologičeskij slovar' russkogo jazyka, t. I, vyp. 1, avtor-sostavitel' N.M. Šanskij, Moskva 1963, „Rocznik Slawistyczny”, t. 26, s. 206-218.

Skulina Tadeusz (1973a), Staroruskie imiennictwo osobowe, cz. I, seria „Prace Onomastyczne”, nr 20, Zakład Narodowy imienia Ossolińskich, Wrocław.

Skulina Tadeusz (1973b), Staroruskie imiennictwo osobowe, cz. II, seria „Prace Onomastyczne”, nr 21, Zakład Narodowy imienia Ossolińskich, Wrocław.

Skulina Tadeusz (1987), Najczestsze chrzestne imiona kobiet w XIV i XV wieku, „Studia Polonistyczne", t. 14/15, s. 251-258.

Skulina Tadeusz (1991), O nie odczytanych i niejasnych nazwach osobowych kobiet w SSNO, „Onomastica”, t. 36, s. 133-158.

Skulina Tadeusz (1993), Z historii i geografii żeńskich formacji patronimicznych w okresie staropolskim, w: Munera linguistica Ladislao Kuraszkiewicz dedicata, 
red. Mieczysław Basaj, Zygmunt Zagórski, Zakład Narodowy im. Ossolińskich, Wrocław, s. 313-320.

Stownik starożytności słowiańskich, t. 6, cz. 1, Zakład Narodowy im. Ossolińskich,

Wrocław 1977; t. 6, cz. 2, Wrocław 1980; t. 7, Wrocław 1982.

Walczak Bogdan (1993), Profesor Tadeusz Skulina (1929-1992), „Informator UAM”,

18 stycznia 1993, s. 1-3.

Walczak Bogdan (2008), Tadeusz Skulina jako historyk języka polskiego, w: Pamięci

Profesora Tadeusza Skuliny w 15. rocznice śmierci, red. Alicja Pihan-Kijasowa, Irena Sarnowska-Giefing, Wydawnicwo PTPN, Poznań, s. 19-26.

Wawrzyńczyk Jan (1975), [rec.:] T. Skulina, Staroruskie imiennictwo osobowe, cz. I,

Wroctaw 1973, cz. II, Wroctaw 1974, „Slavia Orientalis”, nr 2, s. 230-236.

Wójtowicz Marian (2008), Tadeusz Skulina jako badacz najstarszego okresu rozwojowego antroponimii wschodniostowiańskiej, w: Pamięci Profesora Tadeusza Skuliny w 15. rocznicę śmierci, red. Alicja Pihan-Kijasowa, Irena Sarnowska-Giefing, Wydawnicwo PTPN, Poznań, s. 27-34.

Zierhoffer Karol (2008a), Prace Tadeusza Skuliny w zakresie antroponimii, w: Pamięci Profesora Tadeusza Skuliny w 15. rocznice śmierci, red. Alicja Pihan-Kijasowa, Irena Sarnowska-Giefing, Wydawnicwo PTPN, Poznań, s.35-39.

Zierhoffer Karol (2008b), Tadeusz Skulina - językoznawca, polonista, slawista,

w: T. Skulina, Z przeszlości imion i nazwisk oraz dawnych form polskich, seria „Klasycy Nauki Poznańskiej”, t. 25, Wydawnicwo PTPN, Poznań, s. 9-20.

Alicja Pihan-Kijasowa

\section{Professor Tadeusz Skulina - historian of language and onomastician}

Professor Tadeusz Skulina (1929-1992) was born in Katowice but from the Second World War he was connected with Great Poland. Also in Poznań, he studied Polish Studies and following his graduation became employed at Adam Mickiewicz University in Poznań where he completed the consecutive stages of his scholarly career. As a disciple of Professor Władysław Kuraszkiewicz he conducted research on the Polish language of the Old-Polish era and of the 16th century. His doctoral thesis (1964) was devoted to historical phonetics and historical dialectology but soon he changed his scholarly interests and entered the field of Slavic studies, especially East-Slavic languages. In his habilitation thesis he discussed the question of the Old-Ruthenian anthroponymy. This thesis, published in 1973, was the first original, so extensive and detailed thesis about the Old-Ruthenian names. As we know, in the period following the receipt of his habilitation degree Professor Tadeusz Skulina had plans to prepare a monograph about Polish feminine onomastics. He had pursued this for years, however, unfortunately, never 
managed to prepare a synthesis. He only left an unfinished editorial draft of this book. Apart from research activities, Professor Skulina was involved in didactics and also performed responsible administrative functions at the Institute of Polish Philology, was a member of numerous scholarly societies. For his achievements, he received many awards and honours.

Professor Tadeusz Skulina died in 1992 after a long and emaciating illness. The scholarly achievements he has left inspire the successive generations of researchers. He also left unfinished written works and ideas which he never managed to realize.

KeYwords: biographical studies, history of the Polish language, Slavic studies, onomastics, Old-Ruthenian anthroponymy.

prof. dr hab. Alicja Pihan-Kijasowa - profesor zwyczajny w Instytucie Filologii Polskiej Uniwersytetu im. Adama Mickiewicza w Poznaniu, w Zakładzie Lingwistyki Antropologicznej; zainteresowania badawcze: polszczyzna Kresów Wschodnich, kontakty językowe polsko-wschodniosłowiańskie, leksykologia historyczna, język XVII-wiecznych kazań pogrzebowych, historia nauki i instytucji naukowych (głównie wielkopolskich). 
